Cita: Matos, R.; Amaro, N.; Antunes, R.; Rosa, M. (2021). Portuguese adults' concerns on the return to indoor sports practice after confinement due to COVID-19 pandemic - mitigation strategies proposals. Cuadernos de Psicología del Deporte, 21(2), 227-241

\title{
Portuguese adults' concerns on the return to indoor sports practice after confinement due to COVID-19 pandemic - mitigation strategies proposals
}

\author{
Preocupaciones de adultos portugueses sobre el regreso a la práctica \\ deportiva en instalaciones deportivas cubiertas tras el confinamiento al \\ que obligó la pandemia COVID-19- propuestas de estrategias de \\ mitigación
}

\section{Preocupações de adultos portugueses no regresso à prática desportiva em} espaços desportivos cobertos após o confinamento devido à pandemia COVID-19 - propostas de estratégias de mitigação

\author{
Matos, R. ${ }^{1,2}$; Amaro, N. .,2; Antunes, R. ${ }^{1,2,3}$; Rosa, M. ${ }^{2,3}$ \\ ${ }^{1}$ Life Quality Research Centre (CIEQV), Portugal; ${ }^{2}$ Polytechnic of Leiria, Portugal; ${ }^{3}$ ciTechCare - \\ Center for Innovative Care and Health Technology
}

\begin{abstract}
Objective: This study aimed to get an insight of Portuguese adult people concerns about returning to physical activity and sports practice at indoor sports facilities, after confinement due to COVID-19' pandemic. Subsequently, an additional approach to the traditional mitigation strategies was to be proposed. Methods: A total of 173 Portuguese practitioners on indoor physical activity or sports before pandemic participated in this study. A questionnaire asking how much concerned ( 1 - nothing, to 5 - completely) would they be on different contexts and aspects related to this return was applied. Results: respondents were considerably concerned about this theme, especially with touching on common surfaces and proximity to others. Although considerable concerned if having to travel by public transport to the training facility, using locker rooms and with features of the sports' practice itself, the former received the highest concerns. Additionally, we have suggested modifying some objects (or creating others) that may allow their use with body parts other than hands - an important contagion source - and exploiting the possibility of using intermediate instruments on objects and sports equipment manipulation, preventing users from touching their surfaces directly. Conclusion: touching on common surfaces and proximity to others revealed high degrees of concern on the return to indoor sports practice after confinement due to COVID-19 pandemic. Alongside the rules of personal distancing, respiratory etiquette and surfaces hygiene, it is suggested that sports practitioners, whenever possible, use alternative body parts and intermediate instruments that avoid direct contact of hands with surfaces and sport objects.
\end{abstract}




\section{Matos et al.}

Keywords: constraints; affordances; contact surfaces; alternative actions; sports equipment.

\section{RESUMEN}

Objetivo: Este estudio tuvo como objetivo obtener una visión de las preocupaciones de adultos portugueses en lo que refiere al regreso a la actividad deportiva en instalaciones deportivas cubiertas, tras el confinamiento al que obligó la pandemia COVID-19. Posteriormente, se planteó un enfoque adicional a las estrategias tradicionales de mitigación. Métodos: han participado un total de 173 personas que solían practicar actividad deportiva en instalaciones deportivas cubiertas antes de la pandemia. Se aplicó un cuestionario en el que preguntó lo preocupados (1 - nada, a 5 completamente) que estarían en diferentes aspectos relacionados con este regreso. Resultados: Los encuestados estaban extremadamente preocupados, especialmente por tocar superficies de uso común y por la proximidad con otros usuarios. Todos los contextos (desplazamiento en transporte público al lugar de entrenamiento, vestuarios y características de la práctica de la actividad propiamente dicha) fueron señaladas como grandes fuentes de preocupación, sobretodo en cuanto a la primera citada. Se propuso modificar algunos objetos (o crear otros) que permitan un uso con partes del cuerpo distintas de las manos y utilizar instrumentos intermediarios en la manipulación de objetos deportivos. Conclusión: tocar superficies de uso común y la proximidad de otros usuarios reveló altos grados de preocupación al regresar a la práctica deportiva después del confinamiento. Además del respeto de las reglas de distanciamiento personal, etiqueta respiratoria e higiene de superficies, se sugiere que los practicantes utilicen, en la medida de lo posible, partes corporales alternativas e instrumentos intermedios que eviten el contacto directo con superficies y objetos.

Palabras clave: restricciones; affordances; superficies de contacto; acciones alternativas; equipamiento deportivo.

\section{RESUMO}

Objetivo: Este estudo teve como objetivo obter uma visão das preocupações de adultos portugueses sobre o regresso à atividade física e à prática desportiva em instalações desportivas cobertas, após o confinamento devido à pandemia COVID-19. Subsequentemente, ir-se-ia propor uma abordagem adicional às estratégias tradicionais de mitigação. Métodos: Um total de 173 portugueses praticantes de atividade física ou desportiva em instalações desportivas cobertas antes da pandemia participaram no estudo. Todos preencheram um questionário informando o quão preocupados ( 1 - nada, para 5 - completamente) estariam em diferentes contextos e aspetos relacionados com este regresso. Resultados: os entrevistados estão consideravelmente preocupados com tocar em superfícies comuns e com a proximidade a outros utentes. Todos os contextos (uso de transporte público para o local de treino, balneários e caraterísticas da prática desportiva propriamente dita) receberam manifestações de preocupação considerável, com o primeiro a obter as maiores preocupações. Sugeriu-se modificar alguns objetos (ou criar outros) que possam permitir o seu uso com partes do corpo que não as mãos e explorar a possibilidade de usar instrumentos intermediários na manipulação de objetos e equipamentos desportivos, evitando, assim, tocar nas suas superfícies diretamente. Conclusão: tocar em superfícies comuns e proximidade de outros utentes induzem altos graus de preocupação no regresso à prática desportiva após as restrições provocadas pela COVID-19. Além das regras de distanciamento pessoal, etiqueta respiratória e higiene das superfícies, sugere-se que os praticantes, sempre que possível, utilizem partes alternativas do corpo e instrumentos intermediários que evitem o contacto direto das mãos com superfícies e objetos desportivos.

Palavras chave: constrangimentos; affordances; superfícies de contato; ações alternativas; equipamento desportivo

\section{INTRODUCTION}

Portuguese data on regular sports and physical activity of people aged 15 and older are worrying. Eurobarometer 472 (EU, 2018) survey, conducted on December 2017 from the (at the time) $28 \mathrm{EU}$ countries, reveal many negative indicators on this issue. The countries where respondents are least likely to exercise or play sport are Bulgaria, Greece and
Portugal (these are countries where $68 \%$ of people never play sport or exercise). Further, less than one in ten respondents (in Malta, Italy and Portugal) engage in physical activities such as cycling, dancing or gardening, with at least some regularity. In six countries, more than half of respondents never engage in other physical activities. Respondents are also least likely to have done any vigorous physical activity in 


\section{Concerns on the return to indoor sports practice after confinement COVID-19}

Portugal (79\% did none in the previous week), Malta $(78 \%)$ and Italy $(74 \%)$. The proportion that did vigorous physical activity on at least four of the last seven days is the lowest in Italy (5\%), Portugal (7\%), Bulgaria, Greece and Malta (all 9\%). Sport or physical activity at home is less common in Southern European countries, specifically in Spain, Italy (both 16\%) and Portugal (17\%). Interestingly, Portugal was the EU country where engaging in sport or physical activity at work and the use of health or fitness centers has increased the most since 2013 EU report (EU, 2014).

There have been, also, some changes in the reasons for engaging in sport or physical activity since 2013 - that is, comparing EU (2018) results to EU (2014) ones. Following the general EU tendency, Croatia and Portugal had the biggest decrease in the proportion of respondents saying they engage in sport or physical activity to improve their health. Finally, in Portugal, a relatively large proportion of respondents (33\%) mentioned, as a reason not to practice sport more regularly, lack of interest or motivation.

Given the actual pandemic associated with COVID19 , we may conceive the possibility that the reported negative results of adherence to sports and physical activity in Portugal may become even worse, regarding the expectable fear of contamination on indoor sports facilities.

The measures associated with the practice of physical and sports activity, implemented during the successive states of emergency in Portugal, together with the most recent legislative publication that maintain clear and strong restrictions on this same practice, strengthens this concern (for more details on restrictions since May to June 2020, see Methods section).

A possible return to physical activity and sports practice on indoor sports facilities, allowed by the Portuguese government, is not free of concerns regarding a possible contagion. Therefore, to allow a safe return to practice on indoor sports facilities, efforts should focus on possible solutions and preventive measures. Among other theoretical approaches, affordances and constraints theories and models seem to be adequate to the phenomenon that world is dealing with, given the fact that new and safe action possibilities may arise using this perspective. Thus, alternatively to the traditional "respiratory etiquette", surfaces cleaning procedures and physical distancing, value on this COVID-19 combat on indoor sports environments should arise urgently.

Therefore, from an ecological perspective of development, constraints, understood as factors with the potential to influence behavioral changes, format or guide the self-organization of more or less complex systems, whether they are a school of fish moving in orderly formation or a child dealing with a new motor task. Newell's (1986) model of constraints (in line with Bronfenbrenner's bioecological model, 1979), comprises elements of the individual, the environment and the task. The author proposes that changes in motor control derive from the interaction of these factors. In fact, the weight/height/strength that we have, the rules of different sports, the windiness in a dart-throwing contest, all force our actions to adjust to those conditions. That is to say that the actions are restricted or limited by all these conditionings or constraints. Wagman and Carello (2001), exploring the concept of perceptual learning, showed how exploring objects inertial properties allow perceivers in distinguishing objects that afford a given action from those that do not. Additionally, Araújo, Hristovski, Seifert, Carvalho and Davids (2019) conceive action as the realization of an affordance that emerges under constraints.

Speaking of affordances, Gibson (1979) introduced the concept as what a given environment allows a given actor to do. This means that affordances are not properties that a given environment has, intrinsic, but that arise in the dialectics of an individual interaction/environment, being it a mountain to climb, a gap to jump over or a scissors to handle adequately to cut paper properly.

Another relevant aspect is that, although many affordances are easily detectable, it is important that people can understand, in a relatively simple and immediate way, what action/motor solution is expected for a given situation or object. Affordances detection is also a subject of growing interest when it comes to machines/robots. In fact, technological advances habilitate robots to detect affordances for daily objects' grasping (e.g. Katz et al., 2014; Nguyen et al., 2017) and, in general, for interacting with objects in various different ways (Ardon et al., 2020), whether this interaction may imply more or less 


\section{Matos et al.}

representations or affordance-based reactive control for behaviors (Roberts, Koditschek \& Miracchi 2020).

The world of design has a deep concern with objects usefulness and usability. Objects and equipment in general must accomplish their mission (usefulness) and, at the same time, should clearly reveal the way they are supposed to be used (usability). Norman (1988), in an application of the concept of affordance to design, points out that, in his professional area, people care much more about what the user perceives (usability) than with what is true (usefulness). What the designer cares about is whether the person who will use the product he conceived perceives a certain action to be possible. Thus, an object that is intended to be used in a certain way (constraining possibilities, reducing degrees of freedom) should have characteristics that emphasize, in the most immediate and intuitive way possible, that precise desired form of use (i.e., its affordance). This will not be the case of a door that only opens in a given direction and has a handle that allows it to be pulled or pushed. In this case, if the door had no handle, it would immediately be understood that it could only be pushed, due to absence of an affordance to be pulled. As McGrener and Ho (2000) pointed out, affordances may exist independently of the individual's ability to perceive them, that is, the possibility of action. In the relationship between affordances and constraints, the manipulation of the latter (for example, removing a handle on a door that only is intended to be pushed) may highlight affordances so that the subjects, by themselves, become able to find the best motor solutions (in this case, push and not pull). The main objective is that adaptive behaviors emerge from the dynamic interaction between the individual and his/her environment (Hristovski., Davids, Araújo, \& Passos, 2011). Therefore, as pointed out by Marcus (2018), affordances in urbanism are closer to axial, representational maps than to physical space itself. This will facilitate human encounter with objects and environment.

Sports is a domain that gathers a lot of attention. Several recent studies (e.g., Sang et al., 2021) had stressed the consequences of pandemic on quantity and quality of physical activity exerted by subjects. Physical movement restrictions during pandemic may have imposed a decline on physical activity on outdoor environments. However, exercising outdoors may, after pandemic, become a more eligible alternative, either because people may feel safer (Di Sebastiano, Chulak-Bozzer, Vanderloo \& Faulkner, 2020) or because exercising outdoors with family and friends is psychologically rewarding and pleasant (Codina, Pestana \& Stebbins, 2020). Nevertheless, many exercise regularly on indoor facilities. Thus if people are to return to gyms or to other indoor sports facilities, they must feel confident on it. In sports facilities and activities, people share not only spaces but also objects, being them a ball on sports like basketball or handball, or bars that people use to perform push-ups. They also share locker-room, exercise benches, or even water bottles. Handling doorknobs, faucets or toilet flush are usual procedures that, nowadays, may be seen as threats to safety. Providing safety measures and lead people to adopt their own seem to be, therefore, crucial on this process. As Dias, Ferreira, Pereira and Fonseca (2019) have shown, the probability for subjects to renew their membership in fitness centers (in general, not specifically on pandemic) rises when they are satisfied with the services provided. Oppositely, episodes of interruption (as derived from this pandemic) may lead to a higher drop out, especially on subjects that exercise not very often (Rodrigues, Macedo, Teixeira, Cid \& Monteiro (2021). Overall, and as stated by Enríquez-Reyna, Hernández-Cortés, Leiva-Caro, Peche-Alejandro, Molina-Sánchez \& Moreno-Pérez (2020), it is crucial that subjects value exercise (selfefficacy to regulate exercise) and feel that its practice is safe so that they can (re)adhere to it with obvious and substantial benefits. Finally, several studies have shown (Gammon \& Hunt, 2018; Sharma et al., 2020) the impact of social isolation on people's physical and mental health. More recent studies (Antunes et al., 2020; Lesser \& Nienhuis, 2020) revealed that pandemic constraints were associated to high anxiety levels, especially for people that did not keep a regular practice. Thus, even though regular exercise may reduce stress and anxiety, returning to indoor practice may address particular challenges if people feel that indoor facilities may represent potential contagious sources.

The aim of this study was twofold: i) get an insight of Portuguese adult people concerns about returning to physical activity and sports practice at indoor sports facilities, after confinement due to COVID-19' pandemic, and ii) proposing an additional approach to 


\section{Concerns on the return to indoor sports practice after confinement COVID-19}

the traditional "respiratory etiquette", surfaces cleaning procedures and physical distancing, hoping adding value on this COVID-19 combat on indoor sports environments.

It is expectable that a more or less significant part of the inquired subjects feel reluctant to return to indoor practice, fearing a possible contagion following scientific available diffused information of higher probability of COVID-19 infection on indoor/closed facilities.

Besides, it is also very expectable that subjects reveal high degrees of concern on using public transport to the training site, due to the fact of being considerable time on a closed space, close to potential SARS-CoV2 transmitters and touching potentially infected surfaces.

Finally, it is expected that the use of locker rooms and the practice of physical (and/or sports) activity itself elicits similar amounts of concern, especially on the expectancy of touching common infected surfaces or proximity to other users.

\section{METHODS}

\section{Study design and procedure}

This cross-sectional study was conducted in the period between May 28th and June19th. Between March 18th and May 3rd, Portugal underwent three consecutive periods of emergency state, decreed by the Portuguese Republic President. Portugal entered, after, in a state of calamity, decreed by the council of ministers of the government of Portugal on May 4th till the end of June. With the end of the calamity state, Portugal underwent a deconfinement period which is still in progress. On June 1st, sports practice was authorized but under several restrictions. Team-sports, with the exception of Football Professional 1st League, are still not authorized. On gyms, locker rooms cannot be used, equipment cannot be shared and swimming pools are still closed.

This survey involved community adults that used to practice, before COVID-19 pandemic, at least once a week, physical exercise and/or sports (federated or recreational) at closed covered sports facilities. Due to this exceptional pandemic situation and time pressure for a useful and meaningful data recollection tool, a novel questionnaire was conceived. The main purpose was to understand what were subjects' main concerns on hypothetic forthcoming return to indoor exercise practice, regardless of the measures that could be to be taken by those responsible for those facilities. Each questionnaire assessed two domains: sociodemographic data and concerns about imminent return to physical activity and sports practice. The Questionnaire was specifically developed and reviewed by three experts in Sport Sciences. Some pilot-testing was performed to detect eventual doubts in its filling.

Google forms was used as survey platform for electronic distribution, while social media and newspapers were used to advertise and recruit possible volunteers. The volunteers received no compensation for their participation.

Respondents (convenience sample) took an average time of 8 minutes to fill the questionnaire. Procedures followed standards for research in sports medicine and were performed according to the Declaration of Helsinki.

\section{Participants}

Subjects were only eligible if they were aged over 18 years old, had portuguese nationality, lived in Portugal and if, prior to COVID-19 pandemic, they used to practice, at least once a week, physical exercise and/or sports (federated or recreational) at indoor sports facilities. A total of 173 subjects $(34.2 \pm 12.2$ years of age) filled the questionnaire, ranging from 18 to 78 years of age, being $94(54.3 \%)$ women $(31.5 \pm 12.8$ years-old), and $79(45.7 \%)$ men ( $37.5 \pm 10.5$ years-old). Respondents were fully informed regarding the nature of the study, the procedures on data recording and the voluntary nature of their participation. They were also informed that they could withdraw from the study at any time. Subjects provided their consent before the survey's completion and anonymity was guaranteed.

\section{Variables}

In part one, respondents were invited to answer simple questions regarding age and gender. Moreover, they ought to self-report about their habits of physical and/or sports activity by answering the questions that can be found on table 1 . 


\section{Matos et al.}

Besides, a specific branch of questions was elaborated to know respondents intention to return to practice after COVID-19 pandemic restrictions (table 2) and to assess respondents concerns about their return to physical and/or sports activity at indoor sports facilities (tables 3 to 7). They contemplated some of the categories/places refereed to on the manual released by Sports and Youth Portuguese Institute (IPDJ, 2020), which was anchored on the WHO Guidance for organizers of sports events planning mass gatherings during the current outbreak of COVID-19 (WHO, 2020).

Questions required respondents to state how much concerned (1 - nothing, to 5 - completely) would they be with:

- Having to travel by public transport to the training site, concern with touching on common surfaces (bars, rings, etc.), proximity to other users, air quality (contamination or others they might mention?

- In the use of locker rooms, concern with touching on common surfaces (toilet, taps, benches, etc.), number of people in space/interpersonal distance, air quality/contamination or others they might mention?

- In the practice of physical and/or sports activity itself, concern with sharing of objects and training equipment, physical distance between practitioners, air quality/contamination or others they might mention?

\section{Data analysis}

Descriptive statistics (means, standard deviation and frequencies - absolute and percentage values) were used to describe respondents degrees of concern with different contexts (public transport to training site, locker rooms use and practice itself) and features (touching on common surfaces, proximity to others and air contamination) about returning to practice. Inferential statistics - Friedman Tests, followed by a posteriori Wilcoxon tests (non-independent variables) were employed to search for the existence of statistically significant differences between the contexts and between the features indicated before. The option for the use of non-parametric statistical tests was taken subsequently to performing normality tests (Shapiro-Wilk test) to the present variables, which revealed that all of them had a non-normal distribution.

The effect size (r) for each run Wilcoxon signed-rank test was calculated by dividing the $\mathrm{z}$ value by the square root of $n$ (Pallant, 2007), considering $n$ the total number of observations (two by subject, one for each of two compared variables), i.e., the double of subjects' $n$.

IBM SPSS Statistics for Windows, Version 27.0 was the analysis software package used for data examination.

\section{RESULTADOS}

Table 1 shows what were subjects' sports practice habits at indoor sports facilities before COVID-19 pandemic. Pavilions and gymnasiums were the indoor facilities where, before pandemic, more subjects developed their physical indoor practice, far more than on swimming pools or other indoor facilities. Around half of the subjects practiced three or less days per week, with gymnasiums and pavilions receiving over $85 \%$ of the total weekly training sessions in indoor facilities. Physical exercise was the kind of practice subjects exerted more, followed by non-federated sports practice. For physical exercise practice, gymnasiums attendance surpassed clearly other indoor facilities, whereas pavilions took primacy for the development of non-federated sports practice. The great majority of subjects (74\%) used to travel alone to indoor training facilities, essentially by car. Those who did not travel alone shared mostly, also, car, with just a few travelling by public transports. Finally, around $85 \%$ of subjects used to take profit from locker rooms, either for changing equipment and toilet use (almost all) or to take bath (around 78\% of those who used locker rooms).

Intention to return to practice after COVID-19 pandemic restrictions

Table 2 reveals that five out of the six $(83.3 \%)$ respondents that do not intend to return to practice on indoor sports facilities pointed out as a reason the concern of becoming infected with COVID-19. Three (50\%) reported concern of infecting others with COVID-19 and two (33.3\%) lack of motivation to return. 


\section{Concerns on the return to indoor sports practice after confinement COVID-19}

Table 1. Respondents' sports practice habits at indoor sports facilities before COVID-19 pandemic

\begin{tabular}{|c|c|}
\hline $\begin{array}{l}\text { Where was that practice carried out? } \\
\mathrm{n}(\%)\end{array}$ & $\begin{array}{l}\text { Pavilion } \\
\text { Yes } 101(58.4 \%) \\
\text { No } 72(41.6 \%) \\
\text { Gymnasium } \\
\text { Yes } 101(58.4 \%) \\
\text { No } 72(41.6 \%) \\
\text { Swimming Pool } \\
\text { Yes } 32(18.5 \%) \\
\text { No } 141(81.5 \%) \\
\text { Other indoor sports facility } \\
\text { Yes } 8(4.6 \%) \\
\text { No } 165(95.4 \%)\end{array}$ \\
\hline $\begin{array}{l}\text { How often (days per week) did you use to practice before COVID-19? } \\
\mathrm{n}(\%)\end{array}$ & $\begin{array}{l}1 \mathrm{~d} / \text { wk } 8(4.6 \%) \\
2 \mathrm{~d} / \text { wk } 22(12.7 \%) \\
3 \mathrm{~d} / \text { wk } 57(32.9 \%) \\
4-6 \mathrm{~d} / \text { wk } 79(45.7 \%) \\
7 \mathrm{~d} / \text { wk } 7(4 \%)\end{array}$ \\
\hline $\begin{array}{l}\text { Total amount of weekly training sessions per local } \\
\mathrm{n}(\%)\end{array}$ & $\begin{array}{l}\text { Pavilion } 316(40.5 \%) \\
\text { Gymnasium } 353(45.3 \%) \\
\text { Swimming Pool } 57(7.3 \%) \\
\text { Other indoor sports facilities } 54 \\
(6.9 \%)\end{array}$ \\
\hline $\begin{array}{l}\text { For which kind of practice did you use which kind of indoor sports } \\
\text { facilities? } \\
n\end{array}$ & $\begin{array}{l}\text { Physical Exercise (182) } \\
\text { - Pavilion } 54 \\
\text { - Gymnasium } 97 \\
\text {-Swimming Pool } 21 \\
\text { - others } 10 \\
\text { Federated Sports practice (79) } \\
\text { - Pavilion } 67 \\
\text { - Gymnasium } 6 \\
\text {-Swimming Pool } 1 \\
\text { - others } 5 \\
\text { Non-Federated sports practice (107) } \\
\text { - Pavilion } 50 \\
\text { - Gymnasium } 26 \\
\text {-Swimming Pool } 23 \\
\text { - others } 8\end{array}$ \\
\hline $\begin{array}{l}\text { How did you use to move to the training site? } \\
\mathrm{n}(\%)\end{array}$ & $\begin{array}{l}\text { Alone } 128(74 \%) \\
\text { - car } 107 \\
\text { - feet } 19 \\
\text { - bicycle } 2 \\
\text { Not alone } 45(26 \%) \\
\text { - car } 40 \\
\text { - public transport } 5\end{array}$ \\
\hline $\begin{array}{l}\text { In the context of your regular practice, did you use to use the locker rooms? } \\
\mathrm{n}(\%)\end{array}$ & $\begin{array}{l}\text { Yes } 146(84.4 \%) \\
\text { No } 27(15.6 \%)\end{array}$ \\
\hline $\begin{array}{l}\text { If Yes, for which purposes? } \\
\text { n }(\%)\end{array}$ & $\begin{array}{l}\text { Changing equipment } 144(98.6 \%) \\
\text { Use of the toilet } 136(93.2 \%) \\
\text { Bath } 114(78.1 \%)\end{array}$ \\
\hline
\end{tabular}




\section{Matos et al.}

Table 2. Intention to return to regular physical and/or sports activity at indoor sports facilities after COVID-19 pandemic

\begin{tabular}{|c|c|}
\hline $\begin{array}{l}\text { After this COVID-19 pandemic situation, do you expect to return } \\
\text { (or have you already returned) to regular physical and/or sports } \\
\text { activity at indoor sports facilities? } \\
\mathrm{n}(\%)\end{array}$ & $\begin{array}{l}\text { Yes } 150(86.7 \%) \\
\text { - } 34 \text { have already returned } \\
\text { - } 116 \text { intend to return } \\
\text { Undecided } 17(9.8 \%) \\
\text { No } 6(3.5 \%)\end{array}$ \\
\hline $\begin{array}{l}\text { If not, what are the reasons for that decision? } \\
\text { n }(\%)\end{array}$ & $\begin{array}{l}\text { concern to get infected with COVID-19 } \\
\text { Yes } 5(83.3 \%) \\
\text { No } 1(16.7 \%) \\
\text { concern to contaminate others with COVID-19 } \\
\text { Yes } 3(50 \%) \\
\text { No } 3(50 \%) \\
\text { Lack of motivation } \\
\text { Yes } 2(33.3 \%) \\
\text { No } 4(66.7 \%)\end{array}$ \\
\hline
\end{tabular}

Degrees of concern on the return to Physical activity and sports practice on indoor sports facilities after pandemic

Regarding the degrees of concern about several episodes in which COVID-19 may be a threat, in the return (real or hypothetical) to sports in indoor closed facilities, also involving respondents who do not expect to return, results (descriptive data) are presented on tables 3 to 5.

Table 3 shows the degree of concern in the context of the use of public transport for places of practice.

Table 3. Having to travel by public transport to the training site, how much would you be concerned with:

\begin{tabular}{|c|c|c|c|c|c|c|}
\hline Public transport & $\begin{array}{c}\text { Completely } \\
\text { concerned }\end{array}$ & $\begin{array}{c}\text { Highly } \\
\text { concerned }\end{array}$ & $\begin{array}{r}\text { Moderately } \\
\text { concerned }\end{array}$ & $\begin{array}{c}\text { Little } \\
\text { concerned }\end{array}$ & $\begin{array}{c}\text { Nothing } \\
\text { concerned }\end{array}$ & Mean sd \\
\hline $\begin{array}{l}\text { touching on common } \\
\text { surfaces (bars, rings) ? } \\
\mathrm{n}(\%)\end{array}$ & $52(30.1 \%)$ & $43(24.9 \%)$ & $37(21.4 \%)$ & $25(14.5 \%)$ & $16(9.2 \%)$ & $3.52 \pm 1.31$ \\
\hline $\begin{array}{l}\text { proximity to other } \\
\text { travellers? } \\
\mathrm{n}(\%)\end{array}$ & $49(28.3 \%)$ & $47(27.2 \%)$ & $39(22.5 \%)$ & $19(11 \%)$ & $19(11 \%)$ & $3.51 \pm 1.31$ \\
\hline $\begin{array}{l}\text { air quality/contamination? } \\
\mathrm{n}(\%)\end{array}$ & $47(27.2 \%)$ & $42(23.1 \%)$ & $42(23.1 \%)$ & $24(13.9 \%)$ & $22(12.7 \%)$ & $3.38 \pm 1.35$ \\
\hline $\begin{array}{l}\text { Global concern } \\
\mathrm{n}(\%)\end{array}$ & $148(28.3 \%)$ & $132(25.2 \%)$ & $118(22.6 \%)$ & $68(13 \%)$ & $57(10.9 \%)$ & $3.47 \pm 1.24$ \\
\hline
\end{tabular}

Table 4 shows the degree of concern in the context of using locker rooms on indoor sports facilities.

Table 4. Using locker rooms, how much would you be concerned with:

\begin{tabular}{|c|c|c|c|c|c|c|}
\hline Locker Rooms & $\begin{array}{l}\text { Completely } \\
\text { concerned }\end{array}$ & $\begin{array}{l}\text { Highly } \\
\text { concerned }\end{array}$ & $\begin{array}{l}\text { Moderately } \\
\text { concerned }\end{array}$ & $\begin{array}{c}\text { Little } \\
\text { concerned }\end{array}$ & $\begin{array}{c}\text { Nothing } \\
\text { concerned }\end{array}$ & Mean sd \\
\hline $\begin{array}{l}\text { touching on common } \\
\text { surfaces (toilets, lockers, } \\
\text { faucets, etc.)? } \\
\mathrm{n}(\%)\end{array}$ & $36(20.8 \%)$ & $49(28.3 \%)$ & $40(23.1 \%)$ & $26(15 \%)$ & $22(12.7 \%)$ & $3.29 \pm 1.30$ \\
\hline $\begin{array}{l}\text { agglomeration/ proximity } \\
\text { to other users? } \\
\mathrm{n}(\%)\end{array}$ & $44(25.4 \%)$ & $44(25.4 \%)$ & $39(22.5 \%)$ & $30(17.3 \%)$ & $16(9.2 \%)$ & $3.40 \pm 1.29$ \\
\hline $\begin{array}{l}\text { air quality/contamination? } \\
\mathrm{n}(\%)\end{array}$ & $41(23.7 \%)$ & $38(22 \%)$ & $39(22.5 \%)$ & $31(17.9 \%)$ & $24(13.9 \%)$ & $3.24 \pm 1.36$ \\
\hline $\begin{array}{l}\text { Global concern } \\
\mathrm{n}(\%)\end{array}$ & $121(23.3 \%)$ & $131(25.2 \%)$ & $118(22.7 \%)$ & $87(16.8 \%)$ & $62(12 \%)$ & $3.31 \pm 1.24$ \\
\hline
\end{tabular}




\section{Concerns on the return to indoor sports practice after confinement COVID-19}

Table 5 shows the degree of concern in the context of physical and/or sports practice itself

Table 5. In the practice of physical and/or sports activity itself, how much would you be concerned with:

\begin{tabular}{lcccccc}
\hline $\begin{array}{l}\text { Physical and/or sports } \\
\text { Practice itself }\end{array}$ & $\begin{array}{c}\text { Completely } \\
\text { concerned }\end{array}$ & $\begin{array}{c}\text { Highly } \\
\text { concerned }\end{array}$ & $\begin{array}{c}\text { Moderately } \\
\text { concerned }\end{array}$ & $\begin{array}{c}\text { Little } \\
\text { concerned }\end{array}$ & $\begin{array}{c}\text { Nothing } \\
\text { concerned }\end{array}$ & Mean sd \\
\hline $\begin{array}{l}\text { touching on common } \\
\text { surfaces - sharing of objects } \\
\text { and training equipment? }\end{array}$ & $41(23.7 \%)$ & $43(24.9 \%)$ & $34(19.7 \%)$ & $39(22.5 \%)$ & $16(9.2 \%)$ & $3.31 \pm 1.31$ \\
$\begin{array}{l}\mathrm{n}(\%) \\
\text { agglomeration/ proximity to } \\
\text { other users? }\end{array}$ & $35(20.2 \%)$ & $40(23.1 \%)$ & $39(22.5 \%)$ & $42(24.3 \%)$ & $17(9.8 \%)$ & $3.20 \pm 1.29$ \\
$\mathrm{n}(\%)$ \\
$\begin{array}{l}\text { air quality/contamination? } \\
\mathrm{n}(\%)\end{array}$
\end{tabular}

Tables 6 and 7 show results of comparing degrees of concern between and within contexts of practice, including public transport to indoor sports facilities.

Table 6. Comparing mean degrees of concern (Mean \pm sd) between contexts (public transports, locker rooms and practice itself) in each of the three different aspects (touching on common surfaces, agglomeration/ proximity to others and air quality/contamination, respectively) and globally

\begin{tabular}{|c|c|c|c|}
\hline Contexts & touching on common surfaces & $\mathrm{p}$ & $\mathrm{r}(\mathrm{effect}$ size $)$ \\
\hline \multirow[t]{2}{*}{ Public transports $(3.52 \pm 1.31)$} & Locker rooms $(3.29 \pm 1.30)$ & $<0.01$ & -0.15 \\
\hline & Practice itself $(3.31 \pm 1.31)$ & $<0.01$ & -0.14 \\
\hline Locker rooms $(3.29 \pm 1.30)$ & Practice itself $(3.31 \pm 1.31)$ & .949 & - \\
\hline Contexts & agglomeration/ proximity to others? & $\mathrm{p}$ & r (effect size) \\
\hline \multirow[t]{2}{*}{ Public transports $(3.51 \pm 1.31)$} & Locker rooms $(3.40 \pm 1.29)$ & 0.151 & - \\
\hline & Practice itself $(3.20 \pm 1.28)$ & $<0.001$ & -0.20 \\
\hline Locker rooms $(3.40 \pm 1.29)$ & Practice itself $(3.20 \pm 1.28)$ & $<0.01$ & -0.18 \\
\hline Contexts & air quality/contamination? & $\mathrm{p}$ & $\mathrm{r}($ effect size $)$ \\
\hline \multirow[t]{2}{*}{ Public transports $(3.38 \pm 1.35)$} & Locker rooms $(3.24 \pm 1.36)$ & $<0.05$ & -0.11 \\
\hline & Practice itself $(3.08 \pm 1.40)$ & $<0.001$ & -0.20 \\
\hline Locker rooms $(3.24 \pm 1.36)$ & Practice itself $(3.08 \pm 1.40)$ & $<0.01$ & -0.14 \\
\hline Contexts & Global concern & $\mathrm{p}$ & $r($ effect size $)$ \\
\hline \multirow[t]{2}{*}{ Public transports $(3.47 \pm 1.24)$} & Locker rooms $(3.31 \pm 1.24)$ & $<0.05$ & -0.13 \\
\hline & Practice itself $(3.20 \pm 1.22)$ & $<0.001$ & -0.20 \\
\hline Locker rooms $(3.31 \pm 1.24)$ & Practice itself $(3.20 \pm 1.22)$ & $<0.05$ & -0.13 \\
\hline
\end{tabular}




\section{Matos et al.}

Table 7. Comparing mean degrees of concern (Mean $\pm \mathrm{sd}$ ) within contexts (public transports, locker rooms, practice itself and globally) between the three different aspects (touching on common surfaces, agglomeration/ proximity to others and air quality/contamination

\begin{tabular}{|c|c|c|c|}
\hline Aspects of concern & Public transports & $p$ & r (effect size) \\
\hline \multirow[t]{2}{*}{ Touching on common surfaces $(3.52 \pm 1.31)$} & Agglomeration/ proximity to others $(3.51 \pm 1.31)$ & 0.774 & - \\
\hline & Air quality/contamination $(3.38 \pm 1.35)$ & 0.056 & - \\
\hline Agglomeration/ proximity to others $(3.51 \pm 1.31)$ & Air quality/contamination $(3.38 \pm 1.35)$ & $<0.05$ & -0.12 \\
\hline Aspects of concern & Locker rooms & $\mathrm{p}$ & $r($ effect size $)$ \\
\hline \multirow[t]{2}{*}{ Touching on common surfaces $(3.29 \pm 1.30)$} & Agglomeration/ proximity to others $(3.40 \pm 1.29)$ & 0.083 & - \\
\hline & Air quality/contamination $(3.24 \pm 1.36)$ & 0.435 & - \\
\hline Agglomeration/ proximity to others $(3.40 \pm 1.29)$ & Air quality/contamination $(3.24 \pm 1.36)$ & $<0.01$ & -0.19 \\
\hline Aspects of concern & Practice itself & $\mathrm{p}$ & $\mathrm{r}(\mathrm{effect}$ size $)$ \\
\hline \multirow[t]{2}{*}{ Touching on common surfaces $(3.31 \pm 1.31)$} & Agglomeration/ proximity to others $(3.20 \pm 1.28)$ & $<0.05$ & -0.11 \\
\hline & Air quality/contamination (3.08 \pm 1.40$)$ & $<0.01$ & -0.16 \\
\hline Agglomeration/ proximity to others $(3.20 \pm 1.28)$ & Air quality/contamination $(3.08 \pm 1.40)$ & .100 & - \\
\hline Aspects of concern & Globally & $\mathrm{p}$ & $\mathrm{r}($ effect size $)$ \\
\hline \multirow[t]{2}{*}{ Touching on common surfaces $(3.38 \pm 1.16)$} & Agglomeration/ proximity to others $(3.37 \pm 1.15)$ & 0.405 & - \\
\hline & Air quality/contamination $(3.23 \pm 1.25)$ & $<0.05$ & -0.14 \\
\hline Agglomeration/ proximity to others $(3.37 \pm 1.15)$ & Air quality/contamination $(3.23 \pm 1.25)$ & $<0.01$ & -0.16 \\
\hline
\end{tabular}

\section{DISCUSSION APPLICATIONS}

AND

PRACTICAL

This study had a two-folded purpose: i) to get an insight of Portuguese adult people concerns about returning to physical activity and sports practice at indoor sports facilities, after home confination due to COVID-19' pandemic, and ii) proposing an additional approach to the traditional "respiratory etiquette", surfaces cleaning procedures and physical distancing, hoping adding value on this COVID-19 combat on indoor sports environments.

About the former (i), it becomes clear from the questionnaire answers that Portuguese people are considerably concerned with the safety issue when returning to sports practice in indoor facilities these days. As Eurobarometer 472 (EU, 2018) revealed, Portuguese physical activity and sports engagement levels are very low, compared to EU standards. If additional measures are not to be taken, fear of COVID-19 contagion on shared sports facilities and/or on people travelling to practice may lower even more these fragile data. We expected a more or less significant part of the inquired subjects to feel reluctant to return to indoor practice, fearing a possible contagion. Declared intentions revealed that $3.5 \%$ did not intend to return. In fact, $83.3 \%$ of these pointed out as a reason not to return the fear of getting infected with COVID-19. Aditionally, another $9.8 \%$ had not, yet, decided. Thus, $13.3 \%$ of the subjects that were, previously to pandemic, indoor facilities users, were about to stop that attendance. Besides, only $19.7 \%$ of the respondents had, at the moment of answering the questionnaire, effectively resumed indoor practice.

It becomes, therefore, crucial to have countermeasures that may tranquilize them and support their (re)adherence and maintenance to sports. As can be seen on table 1 , over $17 \%$ of the inquired subjects exercised in only one or two days per week. Rodrigues et al. (2021) revealed that episodes of interruption (as derived from this pandemic) may lead to a higher drop out, especially on subjects that exercise not very often. Besides, it is highly probable that outdoors activities receive a higher adherence, following Codina et al. (2020) and Di Sebastiano (2020) results and remarks on this theme. 


\section{Concerns on the return to indoor sports practice after confinement COVID-19}

When analyzing results in three different aspects, we can notice that the concerns about contacting with surfaces, the air quality and the agglomeration/proximity to people had all mean results over 3.20 (exception on concern about air quality in the practice itself), in a scale of 1 (nothing concerned) to 5 (completely concerned). Nevertheless, concerns with air quality were, in all three contexts analyzed (public transports, locker rooms and practice itself), the lowest. In general terms, both touching on common surfaces (including objects and equipment sharing) and agglomeration of users concerns were significantly higher than concerns with air quality/contamination, despite the small effect sizes. In line with Dias et al. (2019), owners and managers of indoor facilities like fitness centers should be aware of these concerns, as the probability of clients to return to those facilities after pandemic will rise if they feel satisfied and safe with the services provided and with countermeasures undertaken against contagion.

Also in global terms, public transports received the highest degree of concern, which was significantly higher than concerns with locker rooms use and with practice itself. This was also true in all three aspects.

If analyzed through percentage frequencies, it worth noting that over $50 \%$ of respondents were completely (5 on a Lickert scale) or highly (4 on a Lickert scale) concerned with the perspective of having to use public transports on their travelling to indoor sports facilities. These figures raised to around 55\% if particularly focusing either on surfaces touching or on agglomeration/proximity to others. As previously stated, is was hypothesized as very expectable that subjects would reveal high degrees of concern on using public transport to the training site, due to the fact of being considerable time on a closed space, close to potential SARS-CoV-2 transmitters and touching potentially infected surfaces. Therefore, results confirm expectancies. Yet, as table 1 revealed, just a few of the subjects actually were travelling on public transports to training sites before pandemic. After resuming, it is expected that, if subjects can manage it, they will be even less.

Finally, and as expected, similar tendency, although with lowest figures, could be found on percentage frequencies of responses to concerns about locker rooms and practice itself. Again, the expectancy of touching common infected surfaces or proximity to other users were prevalent factors for respondents positioning.

We may speculate that practitioners seem more confident on the use of indoor sports facilities than on public transport to those places. Besides, although relevant, taking in account the results, the lower concern about air quality/contamination may come from a conviction that indoor sports facilities' managers are conscientious about the threats and will do whatever possible to lower contagion possibilities, which can be seen as a good signal for a possible return (Dias et al. (2019). Whatever the reasons, there is no doubt that practitioners are concerned about returning to indoor exercise and sports practice. As EnríquezReyna et al. (2020) concluded, it is crucial that subjects feel that their practice is safe so that they can (re)adhere to it.

Thus, results reinforce the relevance of the legal undertaken measures (physical distancing; prohibition of sports practices with physical contact, etc.) as well as the focus on hygiene habits promotion literacy (frequent hands washing, surfaces cleaning, etc).

In this particular domain, a manual was released by Sports and Youth Portuguese Institute, anchored on the WHO Guidance for organizers of sports events planning mass gatherings during the outbreak of COVID-19. Its measures seem reasonable to help prevent the spread of contagious diseases. The highlighted concerns can be mitigated with respiratory etiquette and a wider utilization of individual transportation, preferably by walking and cycling. In parallel, strategies to deal with surfaces follow, most of the times, a cleaning and hygiene methodology. That is, for instance, what normally happens when it comes to sharing objects and equipment in gyms. Therefore, we will be using a different approach on this theme.

Focusing on practical applications that may represent an added value on the prevention of contagious diseases spread (ii), we would like to propose a somehow different and complementary focus when it comes to deal with surfaces, objects and equipment (which received a significant concern on the questionnaire) by the adoption of an affordances and constraints paradigm. Accordingly, besides the interpersonal physical distancing, equipment objects and surfaces hygiene, and frequent hand washing and 


\section{Matos et al.}

use of nasooral protective mask, we propose the following strategies (with and without intermediate instruments) to give people more confidence to return to and/or to engage in sports practice on indoor sports facilities:

- Creation of affordances for action through changes in the characteristics of sports objects and equipment (without intermediate instruments). These changes, when they occur, should induce, more or less immediately, the use of body segments typically not used in those objects' manipulation. These changes will be in line with Araújo et al. (2019) conception of affordances emerging under constraints. Thus, the central objective is to consider the changing of objects (or creating others) in order to allow their use with body parts other than hands, which are priority source of contagion by their frequent and habitual touch on the face (eyes, nose and mouth). As a starting point, we would say that, whenever possible, priority should be given to solutions that dispense the use of any kind of contact. This would be the case of presence/movement sensors for opening doors, lighting or soap/gel dispensing. Or, as previously said, having robots assisting humans on grasping (Katz et al., 2014; Nguyen et al., 2017; Ardon et al., 2020). However, we know that the costs of these solutions can be high and unaffordable for certain public, and even private, indoor sports facilities managing organizations. Accordingly, we will focus on a more low-tech basis. This means that we should think about adapting instruments so that arms and, above all, forearms, could replace the usual central role of the hands. Changing door or locker handles and changing locker rooms' faucets, for instance, which, normally, are designed for manual use, opting for levers or other systems. For instance, an "L" structure may allow pull/push with no need for hands use. Other solutions may involve the use of the feet - pedals embedded in the bottom part of the doors, buttons on the ground or other solutions, with the advantage of facilitating the process when transporting sports objects/equipment in the upper limbs. As a parallel positive outcome, disabled people could also benefit from these changes and adaptations;

- Use of intermediate instruments to prevent users from touching sports objects and equipment surfaces directly. This challenge can be set through different approaches. Modifying objects (e.g. by inserting a slot/notch or drilling them) so that users can use their own instruments/accessories, for individual use, which can be removed from it after use. For example, rubber rings/straps that allow a safe bars and dumbbells grip; a small device that could substitute fingers on, e.g., the selection of programs on a treadmill (e.g. a finger ring with a retractable protrusion - after contacting the desired surface, the protrusion retracts and stays no longer in contact with the outside); a "multipurpose" ring, working as a carabineer, fitting directly into horizontal bars or suspended rings, on gyms. Or, for instance, in public transportation such as a bus, metro or train, to/from training facilities, fitting directly into the horizontal/vertical rod or into the suspended rings, avoiding, in both cases, grabbing them directly. Alternatively, maintaining the structure of the object to be manipulated, using disposable devices that fulfill their mission only once, with, preferably, reuse allowance, entering the cycle of the circular economy. This could be particularly useful, for example, in toilet flushing (disposable pieces or recycled materials). These instruments may assume a more specialized or a more multipurpose character, like a Swiss army knife. Following Wagman and Carello (2001), subjects will explore objects inertial properties and, by doing this, will be able to distinguish objects that afford a given action from those that do not.

Overall, it is our conviction that these proposals may be pertinent and induce more safety and confidence on the return to indoor sports practice. This is a positive outcome from our paper due to Portugal low levels of physical activity and sports practice, when compared with UE countries, as Eurobarometer 472 (EU, 2018) revealed. Indoor practice, we are aware of that, is only a part of physical activity and sports practice. However, Portugal was the EU country where the use of health or fitness centers has increased the most since 2013. Thus, if people become reluctant to return to indoor practice this may negatively affect the figures that are, already, clearly worrying. Results on physical health and on emotional and mental health components may be disastrous, following Antunes et al. (2020) and Lesser and Nienhuis (2020) who underline the high anxiety levels of people that did not keep a regular practice during pandemic.

Authors are aware of the fragility of using a nonvalidated questionnaire. However, as explained before 


\section{Concerns on the return to indoor sports practice after confinement COVID-19}

on methods' section, the exceptional pandemic situation and the very narrow window of opportunity to collect unrepeatable restricted the possible options. Nevertheless, one of the next steps may be to try to validate this instrument, since other pandemic or similar situations may arise in a more or less near future. Another limitation was that the gathered sample was not randomized but a convenience one. Thus, any inferences to the Portuguese population of indoor sports practitioners concerns about returning to practice should be taken carefully. It would also be of interest to assess the degrees of concerns after a more prolonged period of effective return to practice. Finally, it would also worth to investigate if there would be a trend towards a significant dropout due to COVID-19 pandemic concerns.

\section{CONCLUSIONS}

Touching on common surfaces and proximity to others revealed high degrees of concern on the return to indoor sports practice after confinement due to COVID-19 pandemic. Thus, it is crucial to find new solutions that may reduce the risk of contagious. The possibility of virus transmission will decrease on a large scale if, alongside the rules of personal distancing, respiratory etiquette and surfaces hygiene, sports practitioners use their hands much less often. In this paper, we tried to show some ways to drive this change, grouped into two broad categories. On the one hand, inducing strategies of increased use of alternative body parts to the hands. We propose, essentially, the preferential use of forearms or feet, depending on the objects and actions in concrete. This will require, in most cases, a change or adaptation of furniture using parts and handles of a different shape than usual. On the other hand, the use of intermediate instruments that, keeping as main actors the body segments normally used in the actions in question, avoid direct contact with surfaces and objects to be manipulated. These instruments may have a more or less disposable character.

At the same time, it will be important that the suggested changes, if to be implemented, have a corresponding informative and perceptive reinforcement. Objects are viewed according to what we plan to do with them and their utilitarian understanding, not because of their objective physical characteristics. Indoor sports facilities owners and managers, along with sports industry professionals, practitioners and researchers, should work together on the creation, promotion and availability of new products that fit into this approach.

\section{Funding}

This work was supported by national funds through FCTFundação para a Ciência e a Tecnologia, I.P., within the framework of the project UIDP/04748/2020.

\section{Aknowledgments}

The authors would like to thank Dr. Romain Gillain for his precious work revising the Spanish version of this paper' abstract.

\section{REFERENCES}

1. Antunes, R., Frontini, R., Amaro, N., Salvador, R., Matos, R., Morouço, P., \& Rebelo-Gonçalves, R. (2020). Exploring Lifestyle Habits, Physical Activity, Anxiety and Basic Psychological Needs in a Sample of Portuguese Adults During COVID19. International Journal of Environmental Research and Public Health, 17(4360), doi:10.3390/ijerph17124360.

2. Araújo, D., Hristovski, R., Seifert, L., Carvalho, J., \& Davids, K. (2019). Ecological cognition: expert decision-making behaviour in sport. International Review of Sport and Exercise Psychology, 12(1), 1-25. https://doi.org/10.1080/1750984X.2017.1349826.

3. Ardon, P., Pairet, E., Katrin S. Lohan, K.S. Ramamoorthy, S., \& Petrick, R.P.A. (In Press). Affordances in Robotic Tasks - A Survey. Retrieved from https://arxiv.org/pdf/2004.07400v1.pdf $\quad$ on May $16^{\text {th }}$.

4. Bronfenbrenner, U. (1979). The Ecology of Human Development: Experiments by Nature and Design. Cambridge, MA: Harvard University Press.

5. Codina, N., Pestana, J. V., \& Stebbins, R. A. (2020). Fitness training ss a body-centered hobby: The serious leisure perspective for explaining exercise practice. Revista de Psicología del Deporte/Journal of Sport Psychology, 29(2), 7381. Retrieved from https://www.rpdonline.com/index.php/rpd/article/view/11 


\section{Matos et al.}

6. Di Sebastiano, K. M., Chulak-Bozzer, T., Vanderloo, L. M., \& Faulkner, G. (2020). Don't walk so close to me: Physical distancing and adult physical activity in Canada. Frontiers in Psychology, 11, Article 1895. https://doi.org/10.3389/fpsyg.2020.01895

7. Dias, C., Ferreira, A., Pereira, A. R., \& António Manuel Fonseca, A. M. (2019). Examining the relationship between perceived service quality, satisfaction, and renewal intention in Portuguese fitness centers. Revista de Psicología del Deporte/Journal of Sport Psychology, 28(2), 49-58. Retrieved from https://ddd.uab.cat/record/211105

8. Enríquez-Reyna, M. C., Hernández-Cortés, P. L., Leyva Caro, J. A., Peche-Alejandro, P., Molina Sánchez, J. W., \& Moreno-Pérez, N. E. (2020). Dimensions of Exercise Self-efficacy Scale by Type of Activity in Independent Older Adult Women. Cuadernos De Psicología Del Deporte, 20(2), 276-285. https://doi.org/10.6018/cpd.355811

9. EU (2014). Special Eurobarometer 412 Report on Sport and Physical Activity. Brussels: DirectorateGeneral for Communication. doi: 10.2766/73002.

10. EU (2018). Special Eurobarometer 472 Report on Sport and Physical Activity. Brussels: DirectorateGeneral for Communication. doi:10.2766/483047.

11. Gammon, J.; Hunt, J. (2018). Source isolation and patient wellbeing in healthcare settings. $B r . J$. Nurs, $\quad 27(2), \quad 88-91 . \quad$ doi: 10.12968/bjon.2018.27.2.88

12. Gibson, J.J. (1979). The ecological approach to visual perception. Boston: Houghton Mifflin.

13. Hristovski, R., Davids, K., Araújo, D. \& Passos, P. (2011). Constraints-induced Emergence of Functional Novelty in Complex Neurobiological Systems: A Basis for Creativity in Sport. Nonlinear Dynamics, Psychology and the Life Sciences, 15(2), 175-206.

14. IPDJ (2020). Guia para elaboração de um Manual de procedimentos de proteção de praticantes Desportivos e funcionários-covid-19. Retrieved from
https://ipdj.gov.pt/documents/20123/36310/GUI A+PARA+A+ELABORA\%C3\%87\%C3\%83O+ DE+UM+MANUAL+DE+PROCEDIMENTOS+ DE+PROTE\%C3\%87\%C3\%83O+-+COVID19.pdf/e90f86f4-af77-f314-871f$\underline{4 \mathrm{e} 5 \mathrm{ad} 8 \mathrm{e} 76 \mathrm{e} 48 ? \mathrm{t}=1589026658103}$

15. Katz, D., Venkatraman, A., Kazemi, M., Bagnell, J.A., \& Stentz, A. (2014). Perceiving, learning, and exploiting object affordances for autonomous pile manipulation. Auton Robot 37 (4), 369-382. https://doi.org/10.1007/s10514-014-9407-y

16. Lesser, I. A, Nienhuis C. P. (2020). The Impact of COVID-19 on Physical Activity Behavior and Well-Being of Canadians. Int $J$ Environ Res Public Health, 17(11):3899. doi: 10.3390/ijerph17113899

17. Marcus, L. (2018). Overcoming the subject-object dichotomy in urban modeling: Axial maps as geometric representations of affordances in the built environment. Frontiers in Psychology, 9, Article 449. https://doi.org/10.3389/fpsyg.2018.00449

18. McGrenere, J., \& Ho, W. (2000). Affordances: Clarifying and evolving a concept. Proceedings of Graphics Interface 2000, Montreal, May 2000, pp. 179-186.

19. Newell, K.M. (1986). Constraints on the development of coordination. In M.G. Wade \& H.T.A. Whiting (Eds.), Motor development in children: Aspects of coordination and control (pp. 341-360). Dordrecht, The Netherlands: Martinus Nijhoff Publishers.

20. Nguyen, A., Kanoulas, D., Caldwell, D.G., \& Tsagarakis N.G. (2017). Object-based affordances detection with convolutional neural networks and dense conditional random fields. 2017 IEEE/RSJ International Conference on Intelligent Robots and Systems (IROS), Vancouver, BC, pp. 59085915, doi: 10.1109/IROS.2017.8206484.

21. Norman, D.A. (1988). The Psychology of Everyday Things. New York: Basic Books. 


\section{Concerns on the return to indoor sports practice after confinement COVID-19}

22. Pallant, J. (2007). SPSS Survival Manual 3rd Edition. New York, NY: McGraw Hill Open University Press.

23. Roberts, S. F., Koditschek, D. E., \& Miracchi L. J (2020). Examples of Gibsonian Affordances in Legged Robotics Research Using an Empirical, Generative Framework. Frontiers in Neurorobotics, $\quad 14, \quad$ Article 12. https://doi.org/10.3389/fnbot.2020.00012

24. Rodrigues, F., Macedo, R., Teixeira, D., Cid, L., \& Monteiro, D. (2021). Análise comportamental da prática de exercício físico em adultos em contexto de ginásio ao longo de dois anos. Cuadernos de Psicología del Deporte, 21(1), 282292. https://doi.org/10.6018/cpd.433261

25. Sang, X., Menhas, R., Saqib, Z. A., Mahmood, S., Weng, Y., Khurshid, S., ... Shahzad, B. (2021). The Psychological Impacts of COVID-19 Home Confinement and Physical Activity: A Structural Equation Model Analysis. Frontiers in Psychology, 11, Article 3910. https://www.frontiersin.org/article/10.3389/fpsyg.202 $\underline{0.614770}$
26. Wagman, J. B., \& Carello, C. (2001) Affordances and inertial constraints on tool use. Ecological Psychology, 13(3), 173-195, DOI: 10.1207/S15326969ECO1303_1

27. WHO (2020). Considerations for sports federations/sports event organizers when planning mass gatherings in the context of COVID-19. Retrieved from

https://apps.who.int/iris/bitstream/handle/10665/3317 64/WHO-2019-nCoV-Mass_Gatherings_Sports2020.1-eng.pdf. 